\title{
A BIOLUMINESCENT SYSTEM OF FUNGI: PROSPECTS FOR APPLICATION IN MEDICAL RESEARCH
}

\author{
Osipova ZM, Shcheglov AS $\otimes$, Yampolsky IV \\ Department of Biomolecular Chemistry, \\ Shemyakin-Ovchinnikov Institute of Bioorganic Chemistry of the Russian Academy of Sciences, Moscow, Russia
}

\begin{abstract}
Bioluminescence is chemical oxidation of a small luciferin molecule by air catalyzed by luciferase and accompanied by the emission of photons in the visible spectrum. This reaction is used in bioluminescent bioimaging, the method for the visualization of organism's interior. Bioimaging is a popular tool used in medical research. However, it has an unfortunate drawback: it requires introduction of external luciferin to the system before every experiment. In this work we discuss a possibility of developing an autonomous luminescent system in eukaryotes based on the bioluminescent system of higher fungi.
\end{abstract}

Keywords: bioluminescence, bioimaging, tumor models in vivo, photodynamic therapy

Funding: this work was supported by the Ministry of Education and Science of the Russian Federation, Project ID RFMEFI61317X0062.

$\checkmark$ Correspondence should be addressed: Alexander Shcheglov

ul. Miklukho-Maklaya, d. 16/10, Moscow, Russia, 117997; jukart@mail.ru

Received: 15.12.2017 Accepted: 27.12.2017

DOI: $10.24075 /$ brsmu.2018.004

\section{НОВАЯ БИОЛЮМИНЕСЦЕНТНАЯ СИСТЕМА ГРИБОВ: ПЕРСПЕКТИВЫ ИСПОЛЬЗОВАНИЯ В МЕДИЦИНСКИХ ИССЛЕДОВАНИЯХ}

\author{
3. М. Осипова, А. С. Щеглов $\bowtie$, И. В. Ямпольский
}

Отдел биомолекулярной химии,

Институт биоорганической химии им. академиков М. М. Шемякина и Ю. А. Овчинникова РАН, Москва

\begin{abstract}
Биолюминесценция - это химическое окисление небольшой молекулы люциферина кислородом воздуха под действием белка люциферазы, которое сопровождается эмиссией кванта света в видимой области спектра. На основе этой реакции были разработаны различные методы биолюминесцентного имиджинга - получения изображения в живом организме. Они активно используются в медицинских исследованиях. Однако недостатком существующих люминесцентных систем является необходимость добавления люциферина извне перед каждым экспериментом. В настоящей работе обсуждается возможность разработки автономной люминесцентной системы эукариот на основе биолюминесцентной системы высших грибов.
\end{abstract}

Ключевые слова: биолюминесценция, биоимиджинг, опухолевые модели in vivo, фотодинамическая терапия

Финансирование: работа поддержана Министерством образования и науки РФ, идентификатор проекта RFMEFI61317X0062.

$\triangle$ Для корреспонденции: Щеглов Александр Сергеевич

ул. Миклухо-Маклая, д. 16/10, г. Москва, 117997; jukart@mail.ru

Статья получена: 15.12.2017 Статья принята к печати: 27.12.2017

DOI: 10.24075/vrgmu.2018.004

There are thousands of species capable of emitting light. They are referred to as bioluminescent. The majority of them inhabits the depths of the world's seas and oceans, but some glowing species such as insects, worms and fungi can also be found above the water surface. Bioluminescence is a result of luciferase-catalyzed oxidation of a small luciferin molecule by air, accompanied by the emission of a photon in the visible spectrum. This reaction has inspired the development of bioluminescence imaging aimed to visualize processes happening inside the living organism. Bioluminescence imaging has found its way into medical research, including cancer research and development of anticancer drugs. In the last few years this method has become increasingly popular due to its unsurpassed sensitivity in producing accurate images of the interior of living organisms, down to the level of a single cell.

The number of unique luciferin-luciferase pairs occurring in nature is estimated to be as high as 40 [1]. However, in spite of such variety, only a few well-studied bioluminescent systems are currently applied in medical science, including firefly D-luciferin, bacterial and coelenterazine systems. For each type of a luciferin there are a few "complementary" luciferases found in different organisms. For example, for D-luciferin as many as 30 natural luciferases are known, while coelenterazine is "complementary" to 15 luciferases and 8 photoproteins, i.e. stable substrate/protein complexes [2]. Once we know the exact luciferase amino acid sequence, we can insert the gene for this enzyme into another organism's genome and stimulate its expression in it. Introduction of external luciferin into this system will cause the cells to glow. In turn, the emitted light can be registered and subsequently analyzed. Bioimaging is possible not only with cells and tissues but also with cell organelles and for cell-cell/protein-protein interactions. Because different types of luciferins, their functional analogs and luciferases (both natural and synthetic) can be used in 
parallel, bioluminescence becomes an amazingly powerful tool laying the basis for multicolor imaging [3-6].

\section{Bioluminescence in medicine}

Firefly D-luciferin is the most popular substrate used in medical research. To react with luciferase, it needs adenosine triphosphate (ATP). Therefore, a bioluminescence signal can be obtained only in the presence of ATP. Obviously, this means that bioluminescence can be employed to accurately measure ATP concentrations. Because ATP is a universal energy carrier, its levels characterize cell's metabolic potential and may be used to assess cytotoxicity of various drugs or their impact on cell proliferation [7]. In turn, bacterial luminescent systems strongly rely on the presence of such cofactors as flavin mononucleotide (FMN) and nicotinamide adenine dinucleotide hydride (NADH). This property is exploited by bioluminescence-based analytical methods developed to assay $\mathrm{NAD}(\mathrm{P}) \mathrm{H}$, dehydrogenases and various metabolites, like malate, sorbitol and ethanol, whose oxidation is accompanied by the reduction of $\mathrm{NAD}^{+}$to $\mathrm{NADH}$. Used in combination, the firefly and bacterial luminescent systems become a tool for constructing metabolic maps of tumor tissues facilitating discovery of novel approaches to cancer therapy [8-10].

Indeed, the most accurate picture of cancer progression can be obtained using in vivo models. MRI, PET, radiography and similar imaging methods afford to investigate metastasis and angiogenesis of tumors as well as their respond to treatment, especially when it comes to deep tissues. But bioluminescent imaging is preferable to standard methods due to its high sensitivity; 3D-imaging is also possible [11].

Non-invasive imaging techniques normally employ luciferases of Photinus pyralis and Pyrophorus plagiophtalamus (for D-luciferin) and luciferases of Renilla reniformis and Gaussia princeps (for coelenterazine). Recently, the small NanoLuc luciferase has become increasingly popular; it is applied with synthetic luciferin called furimazine [12]. Luciferases are sometimes conjugated to fluorescent proteins and quantum dots to shift the signal to longer wavelenghthusing bioluminescence resonance energy transfer (BRET); this technique is applied to obtain images of deep tissues $[13,14]$.

The phenomenon of bioluminescence is also used in quantum dot-based photodynamic therapy of tumors. A photosensitizer with a powerful cytotoxic effect on cancer cells is delivered to tumors residing in deep tissues where it can be activated using BRET by photons emitted from a luciferase $[15,16]$.

\section{Luminescent system of higher fungi is a new alternative}

An unfortunate disadvantage of luminescent systems used for bioimaging in cancer research is their dependence on luciferin from external sources that needs to be added before every experiment. The only autonomous bacterial luminescent system available nowadays is toxic for eukaryotes. Its key element is the luxCDABE operon. Initially, every attempt to express a bacterial luminescent system in eukaryotic cells resulted in failure. But after a massive structural rearrangement of the operon, bioluminescence in yeast and human cells became finally possible under the condition that luciferin should be added into the system externally [17]. In 2010 after the additional rearrangement of genes in the operon, human cells capable of autonomous luminescence were obtained [18].

At the moment, bacterial luminescent systems are not so readily implemented in eukaryotic cells. To incorporate such systems into a different organism, the same time-consuming manipulations with the operon will probably be needed, including rearrangement of regulatory and operon sequences and introduction of additional linker regions. That said, creating an autonomous luminescent system is still a problem.

For luciferins used in contemporary research, such as D-luciferin and coelenterazine, the problem seems to have no quick solution, because no clear picture of how these molecules are synthesized in the living organism is available. Recently a structure of luciferin of higher fungi (3-hydroxyhispidin) has been described [19] and its bioluminescence studied in depth [20]. A biosynthetic precursor of luciferin in fungi is caffeic acid. Luciferin is produced from it in two steps. First, hispidin is made from two caffeic acid derivatives, namely caffeoyl-CoA and malonyl-CoA, in the presence of polyketide synthase [21]; then, hispidin is converted to luciferin in the presence of hydroxylase (see the Figure).

Caffeic acid is a common secondary metabolite i plants. Transfer of genes coding the proteins involved in synthesis and bioluminescence of luciferin in fungi to plant cells seems to be more realistic solution than manipulations with prokaryotic bacterial genes. But we still believe that autonomously luminescent cells can be obtained not only from fungi but also from other organisms, such as yeast and mammals. Enzymes involved in a two-step process of caffeic acid biosynthesis from L-tyrosine are already known; they are phenylalanine ammonia lyase and cinnamate 4-hydroxylase. Also the genes encoding these enzymes are known (sam8 and sam5, respectively) [22]. Insertion of them into the cluster of genes responsible for fungal luminescence will help to create the first fully autonomous

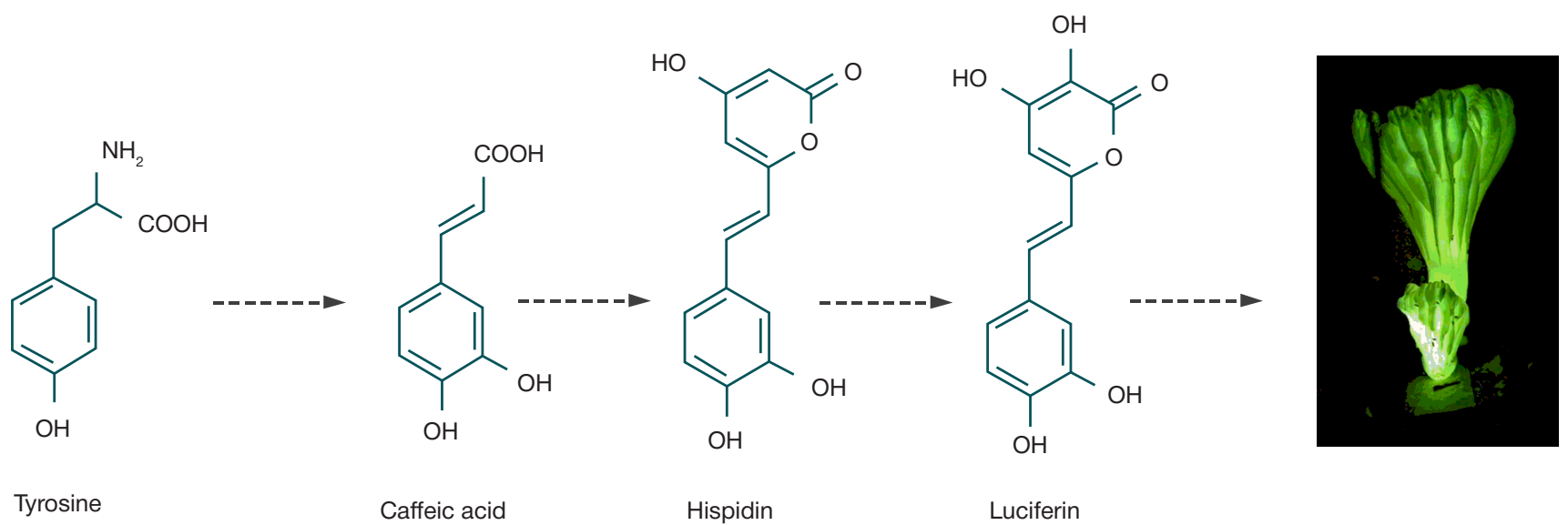

A schematic of luciferin biosynthesis in luminescent higher fungi 
bioluminescent system that can be used for bioimaging in eukaryotic organisms.

\section{CONCLUSIONS}

Bioluminescence imaging applicated in studiesof mechanisms of disease progression or response to treatment has a few advantages over other methods, one of them being incredibly high sensitivity. However, all bioluminescence systems share a common downside: to function, they require a luciferin substrate from external sources. Development of an autonomous luminescent system based on the gene cluster responsible for bioluminescence in higher fungi may offer a potential solution to this problem.

\section{References}

1. Shimomura O. Bioluminescence: chemical principles and methods. Rev.ed. Singapore: World Scientific; 2012.

2. Kaskova ZM, Tsarkova AS, Yampolsky IV. 1001 lights: luciferins, luciferases, their mechanisms of action and applications in chemical analysis, biology and medicine. Chem Soc Rev. 2016; 45 (21): 6048-77. DOI: 10.1039/c6cs00296j.

3. Kiyama M, Saito R, Iwano S, Obata R, Niwa H, A Maki S. Multicolor bioluminescence obtained using firefly luciferin. Curr Top Med Chem. 2016; 16 (24): 2648-55.

4. Hirano T. Molecular origin of color variation in firefly (beetle) bioluminescence: A chemical basis for biological imaging. Curr Top Med Chem. 2016; 16 (24): 2638-47.

5. Nakajim, Y, Ohmiya Y. Bioluminescence assays: multicolor luciferase assay, secreted luciferase assay and imaging luciferase assay. Expert Opin Drug Discov. 2010; 5 (9): 835-49. DOl: 10.1517/17460441.2010.506213.

6. Sun YQ, Liu J, Wang P, Zhang J, Guo W. D-Luciferin Analogues: a Multicolor Toolbox for Bioluminescence Imaging. Angew Chem Int Ed. 2012 Aug 20; 51 (34): 8428-30. DOI: 10.1002/ anie.201203565

7. Guardigli M, Lundin A, Roda A. "Classical" Applications of Chemiluminescence and Bioluminescence. In: Roda A, editor. Chemiluminescence and Bioluminescence: Past, Present and Future. Cambridge: Royal Society of Chemistry; 2010. p. 143-90.

8. Tran Q, Lee H, Park J, Kim SH, Park J. Targeting cancer metabolism-revisiting the Warburg effects. Toxicol Res. $2016 \mathrm{Jul}$; 32 (3): 177-93. DOI: 10.5487/TR.2016.32.3.177.

9. Sattler UG, Meyer SS, Quennet V, Hoerner C, Knoerzer H, Fabian $\mathrm{C}$ et al. Glycolytic metabolism and tumour response to fractionated irradiation. Radiother Oncol. 2010 Jan; 94 (1): 102-9. DOI: 10.1016/j.radonc.2009.11.007.

10. Broggini-Tenzer A, Vuong V, Pruschy M. Metabolism of tumors under treatment: mapping of metabolites with quantitative bioluminescence. Radiother Oncol. 2011 Jun; 99 (3): 398-403. DOI: 10.1016/j.radonc.2011.05.041

11. Slavine NV, McColl RW. Semi-automated Image Processing for Preclinical Bioluminescent Imaging. J Appl Bioinforma Comput Biol. 2015; 4 (1). pii: 114. DOI: 10.4172/2329-9533.1000114.

12. England CG, Ehlerding EB, Cai W. NanoLuc: a small luciferase is brightening up the field of bioluminescence. Bioconj Chem. 2016 May 18; 27 (5): 1175-87. DOI: 10.1021/acs. bioconjchem.6b00112.
13. Schaub FX, Reza MS, Flaveny CA, Li W, Musicant AM, Hoxha S et al. Fluorophore-NanoLuc BRET reporters enable sensitive in vivo optical imaging and flow cytometry for monitoring tumorigenesis. Cancer Res. 2015 Dec 1; 75 (23): 5023-33. DOI: 10.1158/00085472.CAN-14-3538.

14. Kamkaew A, Sun H, England CG, Cheng L, Liu Z, Cai W. Quantum dot-NanoLuc bioluminescence resonance energy transfer enables tumor imaging and lymph node mapping in vivo. Chem Commun. 2016 May 19; 52 (43): 6997-7000. DOI: 10.1039/c6cc02764d.

15. Hsu CY, Chen CW, Yu HP, Lin YF, Lai PS. Bioluminescence resonance energy transfer using luciferase-immobilized quantum dots for self-illuminated photodynamic therapy. Biomaterials. 2013 Jan; 34 (4): 1204-12. DOI: 10.1016/j.biomaterials.2012.0844.

16. Kim YR, Kim S, Choi JW, Choi SY, Lee SH, Kim H et al. Bioluminescence-activated deep-tissue photodynamic therapy of cancer. Theranostics 2015; 5(8): 805

17. Gupta RK, Patterson SS, Ripp S, Simpson ML, Sayler GS. Expression of the Photorhabdus luminescens lux genes (luxA, B, C, D, and E) in Saccharomyces cerevisiae. FEMS Yeast Res. 2003 Dec; 4 (3): 305-13.

18. Close DM, Patterson SS, Ripp S, Baek SJ, Sanseverino J, Sayler GS. Autonomous bioluminescent expression of the bacterial luciferase gene cassette (lux) in a mammalian cell line. PloS one. 2010; 5(8): e12441.

19. Purtov KV, Petushkov VN, Baranov MS, Mineev KS, Rodionova NS, Kaskova ZM et al. The chemical basis of fungal bioluminescence. Angew Chem Int Ed Engl. 2015 Jul 6; 54 (28): 8124-8. DOl: 10.1002/anie.201501779.

20. Kaskova ZM, Dörr FA, Petushkov VN, Purtov KV, Tsarkova AS, Rodionova NS et al. Mechanism and color modulation of fungal bioluminescence. Sci Adv. 2017 Apr 26; 3 (4): e1602847. DOI: 10.1126/sciadv. 1602847

21. Oba $Y$, Suzuki $Y$, Martins GN, Carvalho, RP, Pereira TA, Waldenmaier HE et al. Identification of hispidin as a bioluminescent active compound and its recycling biosynthesis in the luminous fungal fruiting body. Photochem Photobiol Sci. 2017 Sep 13; 16 (9): 1435-40. DOI: 10.1039/c7pp00216e.

22. Berner M, Krug D, Bihlmaier C, Vente A, Müller R, Bechthold A. Genes and enzymes involved in caffeic acid biosynthesis in the actinomycete Saccharothrix espanaensis. J Bacteriol. 2006 Apr; 188 (7): 2666-73. DOI: 10.1128/JB.188.7.2666-2673.2006.

\section{Литература}

1. Shimomura O. Bioluminescence: chemical principles and methods. Rev.ed. Singapore: World Scientific; 2012

2. Kaskova ZM, Tsarkova AS, Yampolsky IV. 1001 lights: luciferins, luciferases, their mechanisms of action and applications in chemical analysis, biology and medicine. Chem Soc Rev. 2016; 45 (21): 6048-77. DOI: 10.1039/c6cs00296j.

3. Kiyama M, Saito R, Iwano S, Obata R, Niwa H, A Maki S. Multicolor bioluminescence obtained using firefly luciferin. Curr Top Med Chem. 2016; 16 (24): 2648-55.

4. Hirano T. Molecular origin of color variation in firefly (beetle) bioluminescence: A chemical basis for biological imaging. Curr Top Med Chem. 2016; 16 (24): 2638-47.

5. Nakajim, Y, Ohmiya Y. Bioluminescence assays: multicolor luciferase assay, secreted luciferase assay and imaging luciferase assay. Expert Opin Drug Discov. 2010; 5 (9): 835-49. DOI: 10.1517/17460441.2010.506213.

6. Sun YQ, Liu J, Wang P, Zhang J, Guo W. D-Luciferin Analogues: a Multicolor Toolbox for Bioluminescence Imaging. Angew Chem Int Ed. 2012 Aug 20; 51 (34): 8428-30. DOI: 10.1002/ anie.201203565.

7. Guardigli M, Lundin A, Roda A. "Classical" Applications of Chemiluminescence and Bioluminescence. In: Roda A, editor. Chemiluminescence and Bioluminescence: Past, Present and Future. Cambridge: Royal Society of Chemistry; 2010. p. 143-90. 
8. Tran Q, Lee H, Park J, Kim SH, Park J. Targeting cance metabolism-revisiting the Warburg effects. Toxicol Res. $2016 \mathrm{Jul}$; 32 (3): 177-93. DOI: 10.5487/TR.2016.32.3.177.

9. Sattler UG, Meyer SS, Quennet V, Hoerner C, Knoerzer H, Fabian $\mathrm{C}$ et al. Glycolytic metabolism and tumour response to fractionated irradiation. Radiother Oncol. 2010 Jan; 94 (1): 102-9. DOI: 10.1016/j.radonc.2009.11.007.

10. Broggini-Tenzer A, Vuong V, Pruschy M. Metabolism of tumors under treatment: mapping of metabolites with quantitative bioluminescence. Radiother Oncol. 2011 Jun; 99 (3): 398-403. DOI: 10.1016/j.radonc.2011.05.041.

11. Slavine NV, McColl RW. Semi-automated Image Processing for Preclinical Bioluminescent Imaging. J Appl Bioinforma Comput Biol. 2015; 4 (1). pii: 114. DOI: 10.4172/2329-9533.1000114.

12. England CG, Ehlerding EB, Cai W. NanoLuc: a small luciferase is brightening up the field of bioluminescence. Bioconj Chem. 2016 May 18; 27 (5): 1175-87. DOI: 10.1021/acs. bioconjchem.6b00112.

13. Schaub FX, Reza MS, Flaveny CA, Li W, Musicant AM, Hoxha S et al. Fluorophore-NanoLuc BRET reporters enable sensitive in vivo optical imaging and flow cytometry for monitoring tumorigenesis. Cancer Res. 2015 Dec 1; 75 (23): 5023-33. DOI: 10.1158/00085472.CAN-14-3538

14. Kamkaew A, Sun H, England CG, Cheng L, Liu Z, Cai W. Quantum dot-NanoLuc bioluminescence resonance energy transfer enables tumor imaging and lymph node mapping in vivo. Chem Commun. 2016 May 19; 52 (43): 6997-7000. DOl: $10.1039 / \mathrm{c} 6 \mathrm{cc0} 2764 d$

15. Hsu CY, Chen CW, Yu HP, Lin YF, Lai PS. Bioluminescence resonance energy transfer using luciferase-immobilized quantum dots for self-illuminated photodynamic therapy. Biomaterials. 2013 Jan; 34 (4): 1204-12. DOI: 10.1016/j.biomaterials.2012.0844.

16. Kim YR, Kim S, Choi JW, Choi SY, Lee SH, Kim H et al. Bioluminescence-activated deep-tissue photodynamic therapy of cancer. Theranostics 2015; 5(8): 805.

17. Gupta RK, Patterson SS, Ripp S, Simpson ML, Sayler GS. Expression of the Photorhabdus luminescens lux genes (luxA, B, C, D, and E) in Saccharomyces cerevisiae. FEMS Yeast Res. 2003 Dec; 4 (3): 305-13.

18. Close DM, Patterson SS, Ripp S, Baek SJ, Sanseverino J, Sayler GS. Autonomous bioluminescent expression of the bacterial luciferase gene cassette (lux) in a mammalian cell line. PloS one. 2010; 5(8): e12441.

19. Purtov KV, Petushkov VN, Baranov MS, Mineev KS, Rodionova NS, Kaskova ZM et al. The chemical basis of fungal bioluminescence. Angew Chem Int Ed Engl. 2015 Jul 6; 54 (28): 8124-8. DOl: 10.1002/anie.201501779.

20. Kaskova ZM, Dörr FA, Petushkov VN, Purtov KV, Tsarkova AS, Rodionova NS et al. Mechanism and color modulation of fungal bioluminescence. Sci Adv. 2017 Apr 26; 3 (4): e1602847. DOI: 10.1126/sciadv.1602847.

21. Oba Y, Suzuki Y, Martins GN, Carvalho, RP, Pereira TA, Waldenmaier $\mathrm{HE}$ et al. Identification of hispidin as a bioluminescent active compound and its recycling biosynthesis in the luminous fungal fruiting body. Photochem Photobiol Sci. 2017 Sep 13; 16 (9): 1435-40. DOI: 10.1039/c7pp00216e.

22. Berner M, Krug D, Bihlmaier C, Vente A, Müller R, Bechthold A. Genes and enzymes involved in caffeic acid biosynthesis in the actinomycete Saccharothrix espanaensis. J Bacteriol. 2006 Apr; 188 (7): 2666-73. DOI: 10.1128/JB.188.7.2666-2673.2006. 